\title{
Decision-Making Styles of Arab Executives: Insights from Tunisia
}

\author{
Driss Boussif \\ University of Central Lancashire, Merseyside, UK
}

\begin{abstract}
The main purpose of this research is to identify the decision-making styles of Tunisian managers. The relationships between their value systems and decision styles and between their decision styles and certain demographic variables (such as level of education, age, etc.) and organizational variables (such as company size, kind of ownership, etc.) are also investigated.
\end{abstract}

In this study, a sample of 215 managers in various organizations was surveyed. Following Ali's questionnaire (1993), managerial decision-making styles were classified into autocratic, pseudoconsultative, consultative, participative, pseudo-participative, and delegative. Furthermore, statistical analysis of the survey data classified managerial value systems into tribalistic, egocentric, conformist, manipulative, sociocentric, and existential. This classification was conducted in accordance with the framework developed by Flowers et al. (1975).

This research is among the very few studies which investigates the characteristics of Tunisian managers, i.e., their value systems and decision styles. It is widely believed that the business philosophy of any country depends, to a large degree, upon the values held by those in management and their decision-making styles. The present study is, thus, a detailed introduction to contemporary Tunisian culture and the way it is managed.

Keywords: decision-making style, Arab executives, value systems, manager's personal attributes, organizational variables

\section{Introduction}

In their quest to better understand managers and their work around the globe, researchers have made significant progress in the methodological and conceptual domains of international and cross-cultural management. They have called our attention to the need for theories and instruments customized to capture attributes of a particular culture or society (e.g., Adler, 1983; All, 1987; Hofstede, 1980).

Many researches argue that managerial attitudes, values, and behaviour differ across national cultures and, thus, effective management styles are culture bound. The underpinning argument here is that there should be congruence between cultural values and norms and decisions making styles and, therefore, the decision making styles must agree with the predominating cultural values to be effective.

Unlike western management theories and models which emphasise delegation, empowerment and power sharing as key component of effective management styles, research in Arab countries (Muna, 1980; Hofstede, 1984) and African countries (Dia, 1994; Blunt and Jones, 1997; Mendonca and Kanungo, 1990) provide extensive evidence 
of an acceptance and legitimisation of more directive and autocratic management styles. They reported that the authority of the manager is accepted as right and proper and subordinates must show respect and obedience to superiors.

However, most such research has been conducted in developed countries and Middle East countries, and no empirical research exists either on the decision making styles or value systems of Tunisian managers. This study will address this gap in the literature, investigating the decisionmaking styles and value systems of Tunisian managers and exploring the predictors of managerial decision styles of Arab managers in this paper, the importance of decision making styles and values study in management will be explored and the research problem, objectives, hypotheses, research methodology, result and significance of the study will be stated.

\section{Research Problem}

Low productivity of Tunisian organizations is a major concern at both micro and macro levels. Ineffective human resource management and lack of congruity between managers' management and decision making styles and employees' acceptance seem to be the two main reasons for low productivity levels. Management Scholars seem to agree that productivity improvement begins with people improvement. Ineffective management practices and low levels of productivity are among the main obstacles to development in the third world. In Tunisia, despite massive investments to improve productivity, it remains low in few sectors. The main reasons of such low productivity, according to Azimi (1995) are:

- Mismanagement and ineffective utilization of human resources;

- Low quality of training systems and programs despite considerable amount of resources spent in formal and informal training programs, and

- Cultural problems which relate to Tunisians workers.

Recent studies indicate that management practices and their effectiveness vary widely from country to country. Such differences are attributed to the diversity of cultural values and beliefs (Ali, 1989a; Ali and Azim, 1993; Hofstede, 1980; Ralston et al., 1993). Despite wide dissemination of information and the growing interdependence of world markets, the distinctive qualities of groups and nations are increasing, rather than decreasing (Ali, 1988; Hofstede, 1983, 1985; Ralston et al., 1993). This fact has stimulated a new interest in investigating value differences and in studying a specific culture in depth (Ali and Al-Shakis, 1991; Bhagat and McQuaid, 1982). Therefore, this research is designed to study decision style in a specific country - Tunisia.

\section{Objectives}

The purpose of the present research is to study the decision-making styles and their predictors of managers in Tunisia using "the decision-making analysis" proposed by Ali's decision making analysis (1993). The research will be partly exploratory in nature and also partly a replication (in a new context) of the original Ali's studies.

The primary focus of the present study is on testing instruments that are culturally relevant to Arab society. More specifically, the present study therefore aims:

- To identify decision making preferences and practices of Tunisian managers;

- To explore the correlates of perceived decision-making styles;

- To relate the decision making styles to value systems for Tunisian managers; and

- To contrast the decision making styles of Tunisian managers with the decision styles of their counterparts from other Middle Eastern countries and to some extent to the western countries (as depicted in previous research studies).

The reason for including national values and culture and their impact on decision style is based on the idea that prevailing values are the most important indicator in the analyses and prediction of human action and behaviour. Indeed, the study of values provides a means to understanding the underlying motivation (the "why") behind individual behaviour, thus enabling 
researchers to bridge the gap between organizational theory and various practical issues pertaining to organizational processes and activities.

\section{Research Hypotheses}

Based on these findings, the current study attempts to test the following hypotheses:

H1: Most Tunisian managers would practice autocratic style in their decision making.

H2: There is a significant correlation between managers' personal attributes such as age, education, gender, management level and the decision-making style.

H3: There is a significant association between organisational variables such as an organisation's activity, size, ownership and decision-making styles.

H4: There is a significant correlation between the decision-maker's values and the decision-making styles.

\section{Literature review}

\section{Classification of decision-making styles}

Decision-making is an integral part of the management process within every organization and at every level (Ali, 1993). According to Weber (1972, p94), "for some scholars of management, decision-making is the distinctive managerial activity." Unfortunately, some individuals enjoy more success than others in making decisions. Recognition of this fact has led to considerable interest in variables (ranging from the physiological to the psychological) that affect decision-making (Taggart \& Robey, 1981).

A simple trait or personality model of leadership and decision-making may explain the differences in decision styles in terms of manager's personality. As such, the early trait and behaviour models assume inherent differences between managers. Vroom and Yetton (1973), who are proponents of contingency models of leadership, however, identify seven situational dimensions which they suggest influencing participation in decision- making. Dansereau et al. (1975) on the other hand, differentiate between subordinates instead of problems. They suggest that managers act differently towards different subordinates. Members of the in-group are consulted like colleagues, whereas members of out-group are treated as hired workers and told what to do.

Ali (1985) modified the decision style scale previously used by Muna (1980) and Vroom and Yetton (1973). Further modifications were made by him (1993), adding pseudoparticipative decision style to the scale, in order to make it more appropriate to use in the Arab countries. This scale, which is used in the present study, includes a description of six alternatives decisions styles: Autocratic style, pseudo-consultative style, consultative style, participative style, pseudo-participative style, delegative style

\section{Factors Influencing Decision-Making Styles}

A number of previous studies have also investigated the variables influencing the adoption of certain decision-making styles. Ali (1989a); Blyton (1984); and Yukl (1994) for example are of the opinion that patterns of organization and individual characteristics influence decision styles. Hofstede (1980) and Tayeb (1988) believe that cultural background influences decision styles. Ali (1989b) argues that decision styles differ significantly by country, sector of enterprise, type of industry, age of manager, field of education, region of childhood, social class, and management function. Ali and Al-Shakis (1985); England et al. (1974); Flowers et al. (1975); and Goodale (1973) are also of the opinion that sector of enterprise, size of organization and management level influence decision style. Adler (1991); Aram and Piraino (1987); Burger and Bass (1979); Kras (1989); and Wright (1981) also believe that management styles vary considerably from culture to culture. Ali (1993) reports that the situation and the type of decision involved influenced decision style.

Maheshwari (1980) argues that the style of decision making in an organization is the result of the complex interaction of several factors, including the context and characteristics of the organization, the nature of the decisions, and the attributes and preferences of the decision-makers. 
Essner and Strother (1962) and Gopula and Hafeez (1964) found decision behavior to be related to educational levels, whereas Blankenship and Miles (1968); and Heller and Yukl (1969) found decision behavior to be related to managerial levels. It is clear from previous discussions that scholars and researchers are in disagreement with regard to two issues, namely, types of decision-making styles adopted by managers, and the variables influencing the adoption of certain decision-making styles.

\section{Cultural influences on decision-making}

Culture is an elusive concept, "a fuzzy, difficult-to-define construct" (Triandis et al., 1986). This view that culture is difficult to define has been shared by others (Ajiferuke \& Boddewyn, 1970; Kelly \& Worthley, 1981). Nonetheless, some reasonable efforts have been made to identify the phenomenon. Hofstede (1980, p: 25) defines culture as "the collective programming of the mind which distinguishes the members of one human group from another." This programming is likely to be ingrained in the individual by adolescence. Ajiferuke \& boddewyn (1970) add that, while over time, each generation may modify or redefine its beliefs and values, culture maybe viewed as those beliefs and values that are widely shared in a specific society at a particular point in time. Although definitions of culture differ greatly, varying from misuse as a synonym for national origin (Bhagat \& McQuaid, 1982) to traditional ideas and beliefs (Kroeber \& Kluckholm, 1952), in the present study, following Krau (1987) "culture will be regarded as the antecedent value system of any group that collectively influences behaviour."

Ali and Wahabi (1995) refer to the differences in management practices and effectiveness from country to country and argue that despite the widespread of information and information technology among various nations and despite emerging global economy, unique characteristics of groups and nations seem to be increasing rather than decreasing. This is in contrast with the claim of universalists about the sheer importance of the environmental influences on management practices. Ali and Wahabi (1995, p: 87-8) suggests that "[T]his fact has stimulated a new interest in investigating value differences and in studying a specific culture in depth."

\section{Research methodology and data collection}

In this study a quantitative (population sample) method was used. The decision to use the quantitative or the questionnaire method in this part of the study was mainly because this study is in part exploratory in nature and in part a replication of the flowers et al. (1975); Ali, Azim, and Krishnan (1995); and Ali, Taqi, and Krishnan (1995) studies, and thus, it seemed appropriate for reasons of consistency to use the same method of inquiry employed by them. Survey methods also made it possible to contact more subjects in a limited time than other methods would have permitted (e.g., interview method).

\section{Sample surveyed:}

Subjects for the present study were decision-makers in various organizations in Tunisia. The results of this study are based on a sample of managers in Tunisian-owned public, mixed and private organizations. It should be pointed out that Tunisia has been chosen for this study because:

- It provides an excellent example of Arab African culture.

- Of lack of such studies in Tunisia and north Africa and

- Tunisia has become a focal point of international business activity. 
Analysis and finding:

Table1: Summary of the main characteristic of the sample $(n=215)$

\begin{tabular}{|c|c|c|}
\hline & Frequency & Percent \\
\hline $\begin{array}{l}\text { Organization activities } \\
\text { Manufacturing } \\
\text { Service } \\
\text { Both }\end{array}$ & $\begin{array}{c}145 \\
3 \\
67\end{array}$ & $\begin{array}{c}67.4 \\
1.4 \\
31.2\end{array}$ \\
\hline $\begin{array}{l}\text { Organization ownership } \\
\text { Government sector } \\
\text { Private sector } \\
\text { Joint sector }\end{array}$ & $\begin{array}{c}65 \\
125 \\
25\end{array}$ & $\begin{array}{l}30.2 \\
58.1 \\
11.7\end{array}$ \\
\hline $\begin{array}{l}\text { Work experience } \\
\text { Fewer than } 5 \text { years } \\
\text { 5-10 years } \\
\text { More than } 10 \text { years }\end{array}$ & $\begin{array}{c}29 \\
82 \\
104\end{array}$ & $\begin{array}{l}13.5 \\
38.1 \\
48.4\end{array}$ \\
\hline $\begin{array}{l}\text { Organization size } \\
\text { Fewer than } 50 \text { employees } \\
50-250 \text { employees } \\
\text { More than } 250 \text { employees }\end{array}$ & $\begin{array}{l}20 \\
97 \\
98\end{array}$ & $\begin{array}{r}9.3 \\
45.1 \\
45.6\end{array}$ \\
\hline $\begin{array}{l}\text { Educational level } \\
\text { General education } \\
\text { Graduate } \\
\text { Postgraduate }\end{array}$ & $\begin{array}{c}26 \\
109 \\
80\end{array}$ & $\begin{array}{l}12.1 \\
50.7 \\
37.2\end{array}$ \\
\hline $\begin{array}{l}\text { Age } \\
\text { less than } 30 \\
30-39 \text { years } \\
\text { More than } 40 \text { years }\end{array}$ & $\begin{array}{c}6 \\
102 \\
107\end{array}$ & $\begin{array}{c}2.8 \\
47.4 \\
49.8\end{array}$ \\
\hline $\begin{array}{l}\text { Job level } \\
\text { Top management } \\
\text { Middle management } \\
\text { Supervisory management }\end{array}$ & $\begin{array}{c}50 \\
116 \\
49\end{array}$ & $\begin{array}{l}23.2 \\
54.0 \\
22.8\end{array}$ \\
\hline $\begin{array}{l}\text { Nationality } \\
\text { Tunisian } \\
\text { Arab } \\
\text { Western }\end{array}$ & $\begin{array}{c}165 \\
37 \\
13\end{array}$ & $\begin{array}{c}76.8 \\
17.2 \\
6.0\end{array}$ \\
\hline
\end{tabular}

The main objective of this study was to determine the most commonly used decision-making style of Tunisian managers, and to test the hypotheses regarding the decision-making styles and the variables influence decision styles. The following table (Table 5.2) exhibits the results of the findings in this section (the distribution of decision making styles displayed by the decision-makers). 
Table 2: Decision-making styles of Tunisian managers

\begin{tabular}{|l|l|l|l|}
\hline Decision style & Frequency & \%frequency & Rank \\
\hline Autocratic & 12 & 5.6 & 6 \\
Pseudo consultative & 61 & 28.3 & 2 \\
Consultative & 81 & 37.7 & 1 \\
Participative & 23 & 10.7 & 3 \\
Pseudo-participative & 16 & 7.4 & 5 \\
Delegatory & 22 & 10.3 & 4 \\
& 215 & 100 & \\
\hline
\end{tabular}

Results reveal that there are a significant relationships of decision-makers' personal attributes with decision-making styles. The results indicate that 93 percent of those who display a consultative decision-making style had graduate or postgraduate education. 96 percent were 30 years old or over, about 73 percent were in middle management. And about 88 percent were Arabs (Arab expatriates and Tunisia nationals). It seems that Arab, young, highly educated, and middle management managers are open minded and are willing to involve subordinates in the decisionmaking process. And therefore employ consultative decision-making style.

\section{Result and discussion}

Based on the findings of previous studies at Middle Eastern countries, it was hypothesized that the majority of Tunisian managers would use an autocratic style in their decision-making. However, this hypothesis was not supported by the findings. The results of the analysis indicate that the autocratic style is the least preferred (5.6\%). The results do not support the hypothesis (H1) that Tunisian executives would be highly committed to an autocratic approach. However, and according to this study, Tunisian managers are highly committed to a consultative style (37.7). Furthermore, the results indicate that executives show a high preference for the pseudo-consultative style (28.3\%). In addition, moderate support is found for participative style (10.7\%). The results, however, do not show that Arab executives avoid a delegative style. Rather, the participants slightly preferred a delegative $(10.3 \%)$ over a pseudo-participative style (7.4\%).

This results is consistent with the findings of a number of previous studies (e.g. Ali, 1989; Ali and Al-Shakhis, 1985; Ali et al., 1995; 1997). However, this result provides strong support that the Arab culture nurtures consultative and pseudoconsultative tendencies (e.g. Ali et al., 1993, Al-Jafary and Hollingsworth, 1983; Muna, 1980). Since the majority of the sample is Arabs and most likely to be Muslims, therefore, as suggested by Ali (1993), this preference may reflect the influence of Islamic and tribalistic values and beliefs, as both Islamic and tribal laws reinforce consultation in conducting all aspects of life. The preference for consultative style may indicate that the decision-making process takes time and delays change, and this is in turn needs to be taken into consideration when doing business in such an environment.

The strong preference of Tunisian executives toward the consultative style is consistent with previous findings in some Middle Eastern countries (Ali, 1993; Muna 1980). This preference may reflect the influence of Islamic and tribalistic values and beliefs, as both Islamic and tribal laws reinforce consultation in conducting all aspects of life. It is the practice of traditional Arab society that members of the entire kinship network or community should be consulted on matters important to their welfare. In fact, consultation mechanisms, a counterpoise to autocratic rule, are a particular feature of traditional Arab society. 
The least preferred styles are autocratic, pseudo-participative, and delegative. These results are evidence, again, that culture and tradition are crucial in understanding management practices. While this indication seems common sense, a cautionary interpretation is still appropriate. A case in point is Yucelt (1986) who suggests that highly industrialized nations tend more toward participative management and less toward the autocratic style while, in lessindustrialized nations, the opposite tends to hold true.

Hypothesis $\boldsymbol{H 2}$, which proposed a significant relationship between decision-makers' personal attributes and decision-making style, is partially supported: results indicate that a decision-maker's education and management levels have a significant effect on decision-making styles. This result is in line with previous findings (e.g. Ali, 1989; Blankernship and Miles, 1968; Essner and Strother, 1962; Goodale, 1973; Gopula, and Hafeez, 1964; Heller and Yukl, 1969). In contrast a decision-maker's age has no significant impact on decision-making styles (see Table 5.5).

Results indicate that there are no significant relationships between decision styles and organization's variables. Results indicate that organizational variables such as an organization's activity, size and ownership have no significant effect on decisionmaking styles (see Table 5.5). this result is not in line with a number of previous studies (e.g. Ali, 1989; England et al., 1974; Flowers et al., 1975; Goodale, 1973).

Results indicate that there is a significant relationship between decision-making styles and value systems consistent with hypothesis $4(\boldsymbol{H} 4)$. Furthermore, when breaking down value systems into its various levels, it was found that a significant relationship between decision-making styles and value systems exist. These results suggest that certain value systems favour the adoption of certain decision-making styles. These results also support Whyte's (1988) argument that the choice of a decision style depends among other things on the value systems of managers.

Al-Jabari (1990) indicated that North African individuals (e.g. Tunisians, Moroccans) are submissive and not willing to initiate change. This may be attributed to the fact that the traditional elite (e.g., political, religious, merchants) preach loyalty and obedience (Barakat, 1993). In addition, individuals in traditional Tunisians families are taught to obey and listen to their elders and authority figures. Wahabi (1993) argued that the colonial powers implanted a sense of cultural inferiority and dependency among the Tunisians. People have experienced conflict between their traditional culture and the Western culture (Said, 1978). Said (1978, p: 39) suggested that "Men have always divided the world up into regions having either real or imagined distinction from each other". Colonialism is an experience that has had an impact on the minds of people in the underdeveloped world (Pfaff, 1995). In business context, most Tunisian organizations have been moulded after French firms and are structured to serve the French market. Likewise, managers are educated and trained using French language and business literature. Thus, their business experience stands in sharp contrast to traditional teaching and the virtue of conformity.

\section{Comparative study of managerial decision styles}

Comparative analysis of decision managerial decision styles of several Middle Eastern countries are tabulated in Table 5.8. The figures in this table are the results of similar studies with the same research instrument. The data in this table indicates the following:

- The dominant managerial decision style among all the studied Middle Eastern countries is consultative, ranging from $54.9 \%$ in Iran (the highest) to $34 \%$ in Kuwait (the lowest).

- Pseudo consultative decision style is one of the dominant decision styles among all Arab managers. This style is scarce among Tunisian manager (28.3\%).

- Autocratic decision style (except in Saudi Arabia, where it is moderately low) is not common in the Middle Eastern context. Delegative style is also minor, ranging from $10.3 \%$ in Tunisia (the highest) to $2 \%$ in Saudi Arabia (the lowest). 
Table 3: Comparative managerial decision-making styles in the selected Middle Eastern countries ( $\%$ respondents)

\begin{tabular}{|c|c|c|c|c|c|}
\hline $\begin{array}{l}\text { Decision-making } \\
\text { style }\end{array}$ & Tunisia & Iran * & Kuwait * & $\begin{array}{l}\text { Arab } \\
\text { expatriates * }\end{array}$ & $\begin{array}{l}\text { Saudi } \\
\text { Arabia ** }\end{array}$ \\
\hline Autocratic & 5.6 & 3.3 & 2 & 3 & 11 \\
\hline $\begin{array}{l}\text { Pseudo- } \\
\text { consultative }\end{array}$ & 28.3 & 1.1 & 20 & 26 & 28 \\
\hline Consultative & 37.7 & 54.9 & 34 & 36 & 39 \\
\hline Participative & 10.7 & 20.9 & 18 & 21 & 20 \\
\hline $\begin{array}{l}\text { Pseudo- } \\
\text { participative }\end{array}$ & 7.4 & 15.2 & 22 & 11 & $* * *$ \\
\hline Delegative & 10.3 & 4.6 & 4 & 3 & 2 \\
\hline
\end{tabular}

\section{Analysis of the study}

The findings indicated that:

- The autocratic style is the least preferred. The results do not support the prediction that Arab executives would be highly committed to autocratic style. Furthermore, the results indicate that Arab executives show a high preference for the consultative and pseudo-consultative style.

- Tunisian managers' decision-making styles are ranked in descending order as: consultative, pseudo-consultative, participative, delegative, pseudoparticipative, and autocratic.

- Moreover, decision-makers' personal attributes such as education and management level have a significant relationship with decision-making styles. Whereas decision-makers' personal attributes such as age and nationality, as well as organizational factors such as an organization's activity, organization's ownership, and organization's size have no significant relationship with decision-making style.

- The primary values of Tunisian managers are egocentric and existentialist. In fact, the inner-directed values (egocentric, existentialist, and manipulative) are the relatively dominant values (55 percent). in contrast, the dominant Arab values are the outer-directed (58 percent), while in the United states the dominant values are inner-directed (60 percent).

- The value systems have a significant impact on the choice of certain decisionmaking styles. This can be considered as an important contribution of this study.

\section{Contribution of the study}

It can be concluded then, that the contribution of this study is twofold: first, it increases our understanding and ability to predict types of decision-making styles which might prevail and which also might be more effective in culturally mixed non western settings. This in turn would enhance our understanding of management 
thinking and practices across nations. In practice, this would be of benefit to multicultural corporations thinking of doing business in such settings in that they need to adopt the appropriate decision-making style so that productivity and profitability could be improved. For instance, the consultative style is the most common decision-making style in Arabic setting, and therefore, this fact should be taken into account so that organizational goals and objectives could be achieved more effectively.

Another contribution of this study is that it highlights the individual as well as the organizational characteristics, which are related to decision-making style also in Arabic setting. The findings in this direction support the concerned decision-making theories, which suggest that a number of individual as well as organizational variables are related to decision style. Once again this would be of benefit to those doing business in such settings in that they should be aware of these characteristics, so that more effective decision-making style could be employed, and therefore, high organizational could probably be achieved.

\section{Conclusion}

The study was primarily investigated the most common decision-making style of Tunisian managers and concerned with investigating the role of a number of variables as predictors of decision-making styles. The findings of the present study confirm the findings of some earlier studies, and conflict with the findings of other studies.

Additionally, the present study investigated the impact of individual variables, the organizational variables, and the value systems on decision-making styles. The impact of value systems on decision-making styles have not been examined empirically in earlier studies especially in a nonwestern work setting, where Arabic culture is a dominant feature of the workforce.

\section{References}

Al-Jafary, A., and Hollingswoth, A. (1983), "An Exploratory Study of Managerial Practices in the Arabian Gulf Region." Journal of International Business Studies, p, 142-152.
.Al-Malik, S. (1989), "Strategic Decision Makers." Unpublished Ph.D. dissertation, Georgia State University, Atlanta.

Ali, A. "Scaling an Islamic Work Ethic. (1987)," Journal of Social Psychology, 128, 5, p, 575-583.

Ali, A. "A Cross-national Perspective of Managerial Work Value Systems." In R. Farmer and E. Mcgoun (eds.), Advances in International Comparative Management, vol. 3. Greenwich, CT: JAI Press, 1988, p, 151-169.

Ali, A. (1989a), "A Comparative Study of Managerial Beliefs about Work in the Arab States." In B. Prasad (ed.), Advances in International Comparative Management, vol. 4. Greenwich, CT: JAI Press, p, 95-112.

Ali, A. (1989b), "Decision Style and Work Satisfaction of Arab Executives." International Studies of Management and Organization, 19, 2, p, 22-37.

Ali, A. (1990), "Management Theory in a Transitional Society: The Arab's Experience." International Studies of Management and Organization, 20, 3, p, 735.

Ali, A. (1985), 'Managerial value systems for working in Saudi Arabia: an empirical investigation', Group and Organization studies, vol.10 (2), p,135-51.

Ali, A. (1982), An empirical investigation of managerial value systems for working in Iraq. Unpublished doctoral thesis, West Virginia University.

Ali, A., and Al-Shakhis, M. (1985),

"Administrators' Attitudes and Practices in Saudi Arabia." Paper presented at the Annual Meeting of the Midwest Academy of International Business, Chicago.

Ali, A., and Schaupp, D. (1992), "Value Systems as Predictors of Managerial Decision Styles of Arab Executives." International Journal of Manpower, 13, 3, p, 19-26.

Ali, A., and Swiercz, P. (1986), "The Relationship between Managerial Decision Styles and Work Satisfaction in Saudi Arabia." In E. Kaynak (ed.), International 
Business in the Middle East. New York: Walter de Gruyter, p, 137-150.

Almaney, A. (1981), "Cultural Traits of the Arabs." Management International Review, 21,3 , p, 10-18.

Badawy, M. (1980), "Styles of Mideastern Managers." California Management Review. 15.Barakat, H. (1993), "The Arab World:

Society, Culture, and State". Berkeley: University of California Press.

Hamady, S, (1960), Temperament and Character of the Arabs. New York: Twayne Publishers.

Roy, C, (1977), "Management Education and Training in the Arab World." International Review of Administrative Sciences, 43, 3, p, 221-228.

Rowe, A., and Boulgarides, J, (1983), "Decision-Styles: A Perspective." Leadership and Organizational Development Journal, 4, 4, p, 3-9.

Yucelt, U, (1986), "Managerial Practices in the Middle East." In E. Kaynak (ed.), International Business in the Middle East. New York: de Gruyter, p, 113-126.

Wahabi, R, (1993), "Values of Arab Executives: Case study of Morocco." Unpublished Ph.D. dissertation, Union Institute, Cincinnati, $\mathrm{OH}$.

Whitely, W, (1981), "Sources of Influences on Managers' Value Dimension Structure, Value Dimension Intensity, and Decision." In C. Dlugos and K. Weierman (eds.),

Management under Differing Value Systems. New York: Walter de Gruyter.

Wright, P, (1981), "Organizational Behavior in Islamic Firms." Management International Review, 21, 2, p, 86-93. 